\title{
Zinc and Iron Agronomic Biofortification of Brassicaceae Microgreens
}

\author{
Francesco Di Gioia ${ }^{1,2, * \mathbb{C}}$, Spyridon A. Petropoulos ${ }^{3}{ }^{\mathbb{D}}$, Monica Ozores-Hampton ${ }^{2}$, \\ Kelly Morgan ${ }^{2}$ and Erin N. Rosskopf ${ }^{4}$ \\ 1 Department of Plant Science, The Pennsylvania State University, University Park, PA 16802, USA \\ 2 South West Florida Research and Education Center, Institute of Food and Agricultural Sciences, \\ University of Florida, Immokalee, FL 34142, USA; ozores@ufl.edu (M.O.-H.); conserv@ufl.edu (K.M.) \\ 3 Department of Agriculture, Crop Production and Rural Environment, University of Thessaly, \\ 38446 N. Ionia, Magnissia, Greece; spetropoulos@uth.gr \\ 4 U.S. Horticultural Research Laboratory, USDA-ARS, 2001 South Rock Rd., Fort Pierce, FL 34945, USA; \\ Erin.Rosskopf@ars.usda.gov \\ * Correspondence: fxd92@psu.edu; Tel.: +1-814-863-2195
}

Received: 27 September 2019; Accepted: 23 October 2019; Published: 25 October 2019

\begin{abstract}
Insufficient or suboptimal dietary intake of iron (Fe) and zinc $(\mathrm{Zn})$ represent a latent health issue affecting a large proportion of the global population, particularly among young children and women living in poor regions at high risk of malnutrition. Agronomic crop biofortification, which consists of increasing the accumulation of target nutrients in edible plant tissues through fertilization or other eliciting factors, has been proposed as a short-term approach to develop functional staple crops and vegetables to address micronutrient deficiency. The aim of the presented study was to evaluate the potential for biofortification of Brassicaceae microgreens through $\mathrm{Zn}$ and Fe enrichment. The effect of nutrient solutions supplemented with zinc sulfate (Exp-1; 0, 5, 10, $20 \mathrm{mg} \mathrm{L}^{-1}$ ) and iron sulfate (Exp-2; 0, 10, 20, $40 \mathrm{mg} \mathrm{L}^{-1}$ ) was tested on the growth, yield, and mineral concentration of arugula, red cabbage, and red mustard microgreens. Zn and Fe accumulation in all three species increased according to a quadratic model. However, significant interactions were observed between $\mathrm{Zn}$ or Fe level and the species examined, suggesting that the response to $\mathrm{Zn}$ and Fe enrichment was genotype specific. The application of $\mathrm{Zn}$ at 5 and $10 \mathrm{mg} \mathrm{L}^{-1}$ resulted in an increase in $\mathrm{Zn}$ concentration compared to the untreated control ranging from $75 \%$ to $281 \%$, while solutions enriched with Fe at 10 and $20 \mathrm{mg} \mathrm{L}^{-1}$ increased Fe shoot concentration from $64 \%$ in arugula up to $278 \%$ in red cabbage. In conclusion, the tested Brassicaceae species grown in soilless systems are good targets to produce high quality $\mathrm{Zn}$ and Fe biofortified microgreens through the simple manipulation of nutrient solution composition.
\end{abstract}

Keywords: biofortification; Brassica; essential micronutrients; microgreens; nutrients deficiency; nutrition security; hidden hunger; anemia

\section{Introduction}

Iron $(\mathrm{Fe})$ and zinc $(\mathrm{Zn})$ are key trace-elements essential for human health, and their dietary deficiency affects over a quarter of the world population, causing physiological disorders, diseases, and even death, thus constituting a primary global public health challenge [1-4]. Iron is a crucial constituent of proteins such as hemoglobin and myoglobin devoted to oxygen transportation within the human body, and it is a constituent and activator of a variety of enzymes that are involved in electron transport, oxidation-reduction reactions, and other biological functions [5]. According to the World Health Organization (WHO), iron deficiency anemia is the most ubiquitous health disorder on the global 
level, and it is closely associated with poor diet, prevalence of cereal-based food, and low consumption of meat, fish, and fruit and vegetables, diets typical of low-income regions in both developed and developing countries [6,7]. Iron is particularly critical for women of childbearing age and young children, and its deficiency increases the risks of maternal mortality. Deficiency can cause stunted growth and irreversible effects on the psychomotor and cognitive function of young children [6,7]. Following Fe in terms of quantitative body requirements, $\mathrm{Zn}$ is a structural constituent of proteins or a catalyzing cofactor involved in the activity of several vital enzymes such as RNA polymerase, superoxide dismutase, cellular signaling proteins, thus playing a key role in multiple biological functions [8,9]. Like Fe, Zn deficiency is associated with poor, non-diversified diets characterized by high prevalence of cereal-based food products which have low $\mathrm{Zn}$ content and bioavailability $[2,4]$. Inadequate intake of $\mathrm{Zn}$ during pregnancy and in pre-school children can permanently impair physical growth, immunity to disease, reproductive function, and neuro-behavioral development [2,9-11]. Similarly to Fe deficiency, the risk of Zn deficiency is significantly higher and widespread in low-income communities in both industrialized and developing countries and primarily affects young children and women $[2,6,7,10,11]$.

Regions with higher risks of Fe and Zn deficiency are generally characterized by soils containing low levels of these nutrients or with properties that limit phytoavailability of trace elements [12]. Moreover, today, the negative effects of climate change on the availability of nutritious food is exacerbating the risks of malnutrition, especially in developing countries [13], and addressing Fe and $\mathrm{Zn}$ deficiency in a growing world population could become an emergency. Increasing awareness about the negative impact, especially on women and children, of such an extended and underlying public health issue raised the attention of the scientific community, and a number of studies have highlighted the importance of supplementing the diet of populations that are at risk of Fe and $\mathrm{Zn}$ deficiency with food enriched with these microelements $[4,6,7,14]$. Besides diversifying the diet and trying to improve food selection habits, biofortification of staple crops has been proposed as a primary solution to address Fe and $\mathrm{Zn}$ deficiency, as well as for other essential micronutrients $[4,15,16]$. A number of research projects have focused on crop breeding and genetic engineering, demonstrating that it is possible to fortify and enhance the bioavailability of $\mathrm{Fe}$ and $\mathrm{Zn}$ in staple crops mainly by: (i) increasing the expression of metal-binding proteins and enzymes; (ii) enhancing the movement and transportation of $\mathrm{Fe}$ and $\mathrm{Zn}$ from the root to the edible portions; (iii) reducing the content of antinutrients that inhibit Fe and $\mathrm{Zn}$ absorption such as phytates, tannins, and dietary fibers; or (iv) increasing the concentration of compounds and factors that promote the absorption of Fe and $\mathrm{Zn}$ such as vitamin C, organic and amino acids, and $\beta$-carotene $[4,14,17-23]$. Nevertheless, this approach has several constraints, and despite the availability of modern breeding and biotechnology tools, the cost and time required to develop genetically biofortified crops make this solution sustainable only in the long run [12]. Especially in the case of engineered crops, due to the high level of regulation and long process of evaluation required, the development and final introduction of a biofortified crop can take years, if not decades, as it requires the approval of plant scientists, policy makers, nutritionists, economists, and last but not least, the acceptance of the entire community [24,25].

As an alternative, agronomic biofortification, which consists of increasing the accumulation of target nutrients in edible plant tissues through fertilization or other eliciting factors has been increasingly proposed in recent years as a simpler, short-term approach to develop functional staple crops and vegetables and address micronutrient deficiency [26-32]. The exogenous application of cations in plants is not new and has been long used in crop cultivation to overcome problems such as the use of marginal irrigation water and high salinity through the regulation of nutrient uptake and the alleviation of nutrient imbalances caused in plants grown under stress conditions [33,34]. Moreover, according to Chrysargyris et al. [35], foliar application of minerals such as Si and Zn may have a positive effect on growth, development, and mineral content of Lavandula angustifolia (Mill.) plants, especially when grown under salinity stress conditions. However, simply increasing the concentration of micronutrients in edible plant tissues is not enough. Crop biofortification, either 
genetic or agronomic, is particularly challenging in the case of Fe and Zn, especially in the case of cereals, legumes, and oilseeds, which are characterized by limited micronutrient uptake and high levels of anti-nutrients such as phytates which significantly limit the absorption and bioavailability of Fe and $\mathrm{Zn}[36,37]$.

A solution to this problem could be the biofortification of sprouted seeds instead of the regular grain crop as has been already proposed for soybean [38], pea [39], brown rice [29], alfalfa, broccoli, radish, and mung bean $[40,41]$. For several crops, it has been demonstrated in fact that during the germination process, as the content of phytate in the seed decreases, the bioavailability of Fe and $\mathrm{Zn}$ increases [29,42,43]. Yet, agronomic biofortification conducted on a large scale also has some risks related to the variability of micronutrient uptake, which cannot be easily standardized due to the variable interactions between genotypes and environments, as well as to the interactions among nutrients during uptake. Repeated supplemental fertilization of the soil with metals like Fe and $\mathrm{Zn}$ can pose environmental and health risks due to their potential leaching into the ground water or the accumulation in the soil or in the plant tissues at excessive levels that can be toxic for the plants and other living organisms, as well as for the consumers $[11,17,44]$. From this perspective, soilless growing systems combined with customized nutrient solutions of known concentrations could allow a standardization of the process of biofortification and fine control of the product quality, while avoiding or minimizing some of the risks associated with agronomic biofortification of soil grown crops [45-48]. A number of studies have in fact proven the potential benefits of soilless growing systems in assuring efficient production of high quality and nutritious food crops, especially of leafy vegetables, even under conditions that are limiting or prohibitive for typical soil cultivation, such as in the case of contaminated soils, lack of growing space or availability of non-conventional growing space, scarce and/or low quality water resources, or other limiting conditions that are easily encountered in developing countries and marginal rural or urban areas [49-51]. In selecting the method of biofortification and the crops that are most suitable for Fe and $\mathrm{Zn}$ biofortification, besides considering the potential physiological limits for the enrichment of a crop with specific micronutrients, it is important to consider the presence of factors that can inhibit or promote micronutrient availability, the presence of antinutritional factors or other risks, the potential for consumer acceptability of the biofortified product, and ideally, it would be good to consider the possibility of developing a method of biofortification simple enough to be transferred to the community in need, allowing them to self-produce biofortified food.

In recent years, microgreens have become increasingly popular as a rich source of vitamins, bioactive compounds, and minerals and have rapidly gained the appellative of "super food" or "functional food" [52-60]. Like sprouts, microgreens are a promising crop category for Fe and Zn biofortification $[55,57,58]$. In fact, using a variety of species, including wild edible plants, even with minimum availability of seeds, microgreens can be easily produced domestically in a relatively short time (7-21 days) within the framework of urban horticulture $[54,57,58,61]$. The multitude of species suitable for the production of microgreens could guarantee a very rich and complete diet, providing a variety of essential nutrients, while the process of germination with the reduction of phytate as observed in sprouts, and the high content of Fe- and Zn-absorption promoters such as ascorbic acid and $\beta$-carotene that characterize microgreens, could assure a high bioavailability of both these trace elements. Although very limited research data is available on microgreen concentrations of Fe and $\mathrm{Zn}$, data reported by Di Gioia et al. [54,58] and Xiao et al. [56] suggest that while there is significant variability among different genotypes, Brassicaceae species could be considered as a good source of both $\mathrm{Fe}$ and $\mathrm{Zn}$, and their actual concentration in young plant tissues is highly influenced by the availability of nutrients during the growth period $[55,58,59]$. Moreover, Brassicaceae microgreens are very popular, relatively inexpensive, easy to germinate and grow, and have great potential health-benefits thanks to their high content of glucosinolates, vitamins, and polyphenols [46,52,53,57-59,62]. With such considerations, it is worth exploring the efficacy and potential implications of producing Fe and Zn agronomically biofortified Brassicaceae microgreens. To this purpose, a study was conducted to investigate the effects of increasing levels of $\mathrm{Zn}$ and Fe supplied through the nutrient solution on yield 
components and the mineral profiles of three popular species of Brassicaceae microgreens, namely arugula, red cabbage, and red mustard.

\section{Materials and Methods}

\subsection{Experimental Site, Treatments, and Growing System}

Two experiments were conducted during the spring of 2016, in a high tunnel covered with polyethylene film and lateral openings for natural air circulation, at the University of Florida (UF) Institute of Food and Agriculture Science (IFAS) Southwest Florida Research and Education Center (SWFREC) located in Immokalee, FL.

Three Brassicaceae species commonly used to produce microgreens were selected for both experiments: arugula (Eruca sativa (Mill.) Thell.) cv. 'Astro', red cabbage (Brassica oleracea L. var. capitata) cv. 'Red Acre' and red mustard (Brassica juncea (L.) Czern.) cv. 'Purple Osaka'. Seeds of all three species were provided by Seedway LLC (Lakeland, FL, USA) and tested for germinability prior to seeding. Seeds were of high quality with a germination rate of $98 \%, 95 \%$, and $97 \%$ at constant $20{ }^{\circ} \mathrm{C}$, while the number of seeds per $\mathrm{g}$ was $520 \pm 6.4,180 \pm 2.1$, and $417 \pm 10.8$ (mean $\pm \mathrm{SD}, n=5$ ) for arugula, red cabbage, and red mustard, respectively.

In both experiments, microgreens were grown in a soilless system using grow channels (Cropking Inc., Lodi, $\mathrm{OH}$, USA) $0.25 \mathrm{~m}$ wide by $2.8 \mathrm{~m}$ long placed on adjustable benches with a slope of approximately $5 \%$ to enhance nutrient solution movement. Each channel hosted the three species grown on BioStrate-Felt (Cropking Inc., Lodi, OH, USA) growing mats $\left(23 \times 60 \mathrm{~cm}=1380 \mathrm{~cm}^{2}\right)$. Plants were fertigated with a half-strength modified Hoagland nutrient solution containing selected levels of zinc $(0,5,10$, and $\left.20 \mathrm{mg} \mathrm{L}^{-1}\right)$ in the first experiment (Exp-1), and selected levels of iron $\left(0,10,20\right.$, and $\left.40 \mathrm{mg} \mathrm{L}^{-1}\right)$ in the second experiment (Exp-2). The standard nutrient solution was prepared using deionized water containing ( $\left.\mathrm{mg} \mathrm{L}^{-1}\right) 105.1$ nitrogen, 15.5 phosphorus, 117.4 potassium, 26.0 magnesium, 92.5 calcium, 34.6 sulfur, 1.20 iron, 0.60 manganese, 0.15 zinc, 0.30 boron, 0.08 copper, and 0.03 molybdenum. Both macro and micronutrients were added to the nutrient solution using simple fertilizer grade salts such as calcium nitrate, potassium nitrate, ammonium nitrate, monopotassium phosphate, potassium sulphate, magnesium sulfate, copper EDTA, manganese sulfate, sodium borate, and sodium molybdate (Helena, Immokalee, FL, USA). In Exp-1, using laboratory grade zinc sulfate heptahydrate $\left(\mathrm{ZnSO}_{4}+7 \mathrm{H}_{2} \mathrm{O}\right.$, Sigma Aldrich, St. Louis, MO, USA), zinc level was adjusted based on the predefined treatment rates $(0,5$, 10 , and $\left.20 \mathrm{mg} \mathrm{L}^{-1}\right)$, while iron concentration was the same for all $\mathrm{Zn}$ enrichment treatments $\left(1.20 \mathrm{mg} \mathrm{L}^{-1}\right)$. In Exp-2, using laboratory grade iron sulfate heptahydrate $\left(\mathrm{FeSO}_{4}+7 \mathrm{H}_{2} \mathrm{O}\right.$, Sigma Aldrich, St. Louis, $\mathrm{MO}, \mathrm{USA})$, iron levels were adjusted based on the predefined treatment rates $\left(0,10,20\right.$, and $\left.40 \mathrm{mg} \mathrm{L}^{-1}\right)$, while zinc concentration was the same for all Fe enrichment treatments $\left(0.15 \mathrm{mg} \mathrm{L}^{-1}\right)$. The final nutrient solution had an average electrical conductivity (EC) of $1.25 \mathrm{dSm}^{-1}$ and $\mathrm{pH}$ 6.2. The nutrient solutions, stored in separate containers for each level of $\mathrm{Zn}$ and Fe in Exp-1 and Exp-2, respectively, were pumped to the growing benches and delivered at the upper end of each channel through an irrigation line with five pressure-compensated drippers (each with a delivery rate of $4.0 \mathrm{~L} \mathrm{~h}^{-1}$ ) per channel. Particular attention was paid to leveling the growing channels and defining the length of fertigation events to assure adequate and uniform distribution of the nutrient solution along the width and length of each channel at each fertigation event. The nutrient solution delivery was managed with an open cycle system and a $20 \%$ minimum drainage fraction in order to ensure that the entire growing mat area was completely wet at every fertigation event, while avoiding nutrient accumulation in the growing mats. The frequency of fertigation events of one or two minutes was adjusted through a timer that activated the individual pumps on each nutrient solution tank. The excess nutrient solution was collected in buckets at the end of each channel to measure the drainage volume and then was discarded. In a real production scenario, a closed cycle system with recirculating nutrient solution would be used for producing $\mathrm{Zn}$ and Fe enriched microgreens in order to optimize the use of water and nutrients; however, for the purpose of this research, an open management cycle was used to maintain a constant $\mathrm{Zn}$ and Fe concentration 
during the entire growing cycle in order to record the actual effect of $\mathrm{Zn}$ and Fe addition in the nutrient solution on plant nutrient content. Treatments were replicated three times and were arranged according to a split plot design, in which the single channels constituted the main plots and the growing mats of each species constituted the sub-plots.

\subsection{Planting Date, Seeding Density, Treatment Differentiation, and Harvest}

All three species were sown on 15 February 2016 and on 29 February 2016 for Exp-1 and Exp-2, respectively. Seeding density was defined after preliminary experiments, considering the number of seeds per gram and the germinability of the batch of seeds of each species. The equivalent of 55,125 , and $67 \mathrm{~g} \mathrm{~m}^{-2}$ of seeds were used in order to obtain a density of $2.9,2.2$, and 2.8 seeds cm $\mathrm{cm}^{-2}$ for arugula, red cabbage, and red mustard, respectively. After sowing, deionized water was sprayed on top of the seeds using a misting nozzle and growing benches were covered for two days with a white on black polyethylene film allowing seed germination in the dark in both experiments. After complete germination, the third day after sowing (on 18 February 2016 and 3 March 2016, in Exp-1 and Exp-2, respectively), the growth benches were uncovered and fertigation treatments with different levels of $\mathrm{Zn}$ or Fe enrichment were applied at each fertigation event until harvest. Microgreens of all three species were harvested 11 days after sowing (DAS) on 26 February 2016 and 11 March 2016 in Exp-1 and Exp-2, respectively. At harvest, all three species had fully expanded and turgid cotyledons with the appearance of the tips of the first true leaves. Harvest was conducted by cutting the shoots a few millimeters above the growing pad surface using clean cutter blades. To avoid border effects, a $2.5 \mathrm{~cm}$ strip on each end of the growing mat was excluded from the sampling area. Harvested microgreens were weighed to determine the fresh yield $\left(\mathrm{g} \mathrm{m}^{-2}\right)$ and a pre-marked $10 \times 10 \mathrm{~cm}$ area in the middle section of each growing area was used for counting the number of germinated shoots to determine the shoot population density (shoots $\mathrm{m}^{-2}$ ) and the mean shoot fresh weight $\left(\mathrm{mg} \mathrm{shoot}^{-1}\right)$. Dry matter

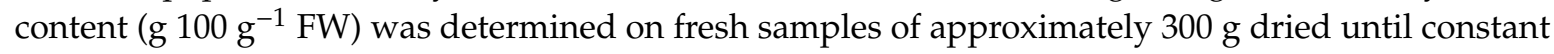
weight at $65^{\circ} \mathrm{C}$ in a forced-air oven. Dried plant tissue samples were ground using a mill and passed through a $1.0 \mathrm{~mm}$ sieve and were used to determine the concentration of $\mathrm{P}, \mathrm{K}, \mathrm{Ca}, \mathrm{Mg}, \mathrm{Cu}, \mathrm{Fe}$, and $\mathrm{Zn}$.

\subsection{Mineral Analysis}

Dry and finely ground microgreen tissue samples collected at harvest were analyzed to determine the concentration of $\mathrm{P}, \mathrm{K}, \mathrm{Ca}, \mathrm{Mg}, \mathrm{Cu}, \mathrm{Fe}$, and $\mathrm{Zn}$ using the dry ash combustion digestion method [63,64]. Analyses were performed at the University of Florida in the soil and plant analysis laboratory at the Southwest Research and Education Center, using an inductively coupled plasma atomic emission spectrometry (ICP-AES) system (OES Optima 7000 DV, PerkinElmer, Santa Clara, CA, USA). Dry plant tissue samples of $1.5 \mathrm{~g}$ were weighed and dry ashed at $500{ }^{\circ} \mathrm{C}$ for $16 \mathrm{~h}$ [65]. The ash was equilibrated with $15 \mathrm{~mL}$ of $0.5 \mathrm{M} \mathrm{HCl}$ at room temperature for $0.5 \mathrm{~h}$. The solution was decanted into $15 \mathrm{~mL}$ plastic disposable tubes and placed in a refrigerator at $\angle 4{ }^{\circ} \mathrm{C}[66]$ until analyses using ICP-AES were performed using calibration and quality assurance procedures as described by Munter et al. [67]. A three-point calibration was performed with standards within the expected range of concentrations. A quality control sample representing a blank, standard, or replicate was included after every 10 unknows in each sample set. Macronutrients and trace-element concentrations determined on dry weight (DW) basis ( $\mathrm{mg} \mathrm{kg}^{-1}$ of DW) were then transformed and presented on a fresh weight (FW) basis (mg $100 \mathrm{~g}^{-1}$ of FW) using the dry matter percentage previously determined on the same plant tissue samples (see Section 2.2).

\subsection{Statistical Analysis}

Linear and quadratic regression analyses were used to estimate the yield and nutrient component response of each species to $\mathrm{Zn}$ and Fe concentration in the nutrient solution using the regression procedure (PROC REG) of the Statistical Analysis System software (SAS Institute, Cary, NC, USA). Collected data were subject to analysis of variance using the General Linear Models procedure of the 
Statistical Analysis System software (SAS Institute, Cary, NC, USA). Significant differences between treatments were analyzed using the Student-Newman-Keuls post-hoc multiple comparison procedure at $p=0.05$.

\section{Results and Discussion}

\subsection{Microgreens Biometric Response to Zinc (Zn) Enrichment}

Based on regression analysis shoot density, fresh yield, single-shoot fresh weight, and dry matter content responded to increasing levels of $\mathrm{Zn}$ in the nutrient solution in a general quadratic fashion (Figure 1 and Table S1). Nevertheless, while the intercept was always significantly different from zero, slope and quadratic coefficient were significant for fresh yield, shoot fresh weight, and dry matter content only in the case of arugula; for the same parameters $R^{2}$ values of the quadratic model were $0.63,0.70$, and 0.42 , respectively. Apart from arugula and for the three parameters mentioned above, quadratic coefficients were in general very low suggesting a lack of response of red cabbage and red mustard to increasing levels of $\mathrm{Zn}$ in the nutrient solution (Figure 1A,B). The low values of $R^{2}$ observed for both the linear and quadratic model in the case of red cabbage and red mustard for all the biometric parameters examined also suggested a low biometric response to the application of increasing $\mathrm{Zn}$ levels (Table S1).

The $\mathrm{Zn}$ concentration in the nutrient solution had no effect on the tested parameters (shoot population density, fresh yield, shoot fresh weight, and dry matter content), which were affected only by the species, whereas no significant interaction between the studied factors ( $\mathrm{Zn}$ levels and species) was observed (Table 1). As expected, the shoot population density was influenced by the seeding density and germination rate of each species and was highest for arugula, which had the highest seeding density and germinability. In contrast, the lowest values for seeding density and germinability were recorded for red cabbage. Fresh yield was lower for arugula compared to the other two species, which may be explained by the smaller seed size and the different plant morphology that characterizes this species compared to the other two brassicas. Consequently, the single shoot mean fresh weight was highest in red cabbage and lowest for arugula, which had the lowest yield and the highest shoot population density, despite the fact that both Brassica species did not differ in terms of fresh yield. Fresh yield and single-shoot fresh weight values in the present study were comparable or higher than those observed in the case of rapini microgreens grown in a similar growing system with the same standard nutrient solution [59]. Dry matter content was higher in red cabbage, followed by arugula, and red mustard, and observed values were in the same range of values observed for rapini microgreens grown in a greenhouse using a similar growing system and the same standard nutrient solution [59].

In a similar study, Wei et al. [29] observed no effect on seed germination in the case of brown rice treated with $\mathrm{ZnSO}_{4}$ solutions up to $150 \mathrm{mg} \mathrm{L}^{-1}$, and Ramezani et al. [68] reported no significant effect of $\mathrm{Zn}$ foliar application on the yield of Carum copticum. In the case of soybean sprouts treated with zinc sulfate, testing several application rates from 0 to $100 \mathrm{mg} \mathrm{L}^{-1}$, Zou et al. [38] observed a slight increase in fresh yield with $10 \mathrm{mg} \mathrm{L}^{-1}$ of $\mathrm{Zn}$ and a slight yield decrease with $100 \mathrm{mg} \mathrm{L}^{-1}$, while seed germination remained the same or was improved for most of the treated seeds. In contrast, an increase in fresh yield was observed in pea sprouts soaked or sprayed with solutions containing from 10 to $60 \mathrm{mg} \mathrm{L}^{-1}$ of $\mathrm{Zn}$ compared to the untreated control [39]. Similarly, Moghimipour et al. [69] and Hassanpouraghdam et al. [70] suggested that $\mathrm{Zn}$ application may increase essential oil yield in holy basil (Ocimum sanctum) and affect essential oil composition of basil (Ocimum basilicum). In contrast to the present study, Ghorbanpour et al. [71] reported a positive effect of foliar application of Zn up to $10 \mathrm{mg} \mathrm{kg}^{-1}$ on root and dry weight of sweet basil (Ocimum basilicum L.), a difference that could be due to the application method (foliar vs nutrient solution) as well as to the broader range of the applied $\mathrm{Zn}$ levels (0-50 $\left.\mathrm{mg} \mathrm{kg}^{-1}\right)$. Moreover, Ahl and Omer [72] suggested that the combined application of $\mathrm{Zn}$ and Fe (400 ppm and 200 ppm, respectively) increased plant height and biomass production of coriander (Coriandrum sativum L.). In the study of Hanif et al. [73], who used a similar experimental layout 
to the present study, the addition of very low Zn concentrations (up to $0.09 \mathrm{mg} \mathrm{L}^{-1}$ ) in the nutrient solution resulted in the best growth in terms of plant height and fresh yield in sweet basil, although for all the applied $\mathrm{Zn}$ concentrations $\left(0.09-0.2 \mathrm{mg} \mathrm{L}^{-1}\right)$, these parameters were higher when compared to the control treatment $\left(0 \mathrm{mg} \mathrm{L}^{-1}\right.$ of $\left.\mathrm{Zn}\right)$. These differences between studies may indicate that the positive effects of $\mathrm{Zn}$ application are limited to very low concentrations of $\mathrm{Zn}$ and further increases of $\mathrm{Zn}$ content in nutrient solution may have limited impact or could have an adverse effect due to toxicity symptoms. However, considering that the aim of the present study was the biofortification of microgreen shoots with adequate amounts of $\mathrm{Zn}$ for nutritional purposes, high $\mathrm{Zn}$ concentrations were tested in order to define the optimal ratio between high yield and high $\mathrm{Zn}$ content in the young shoots.

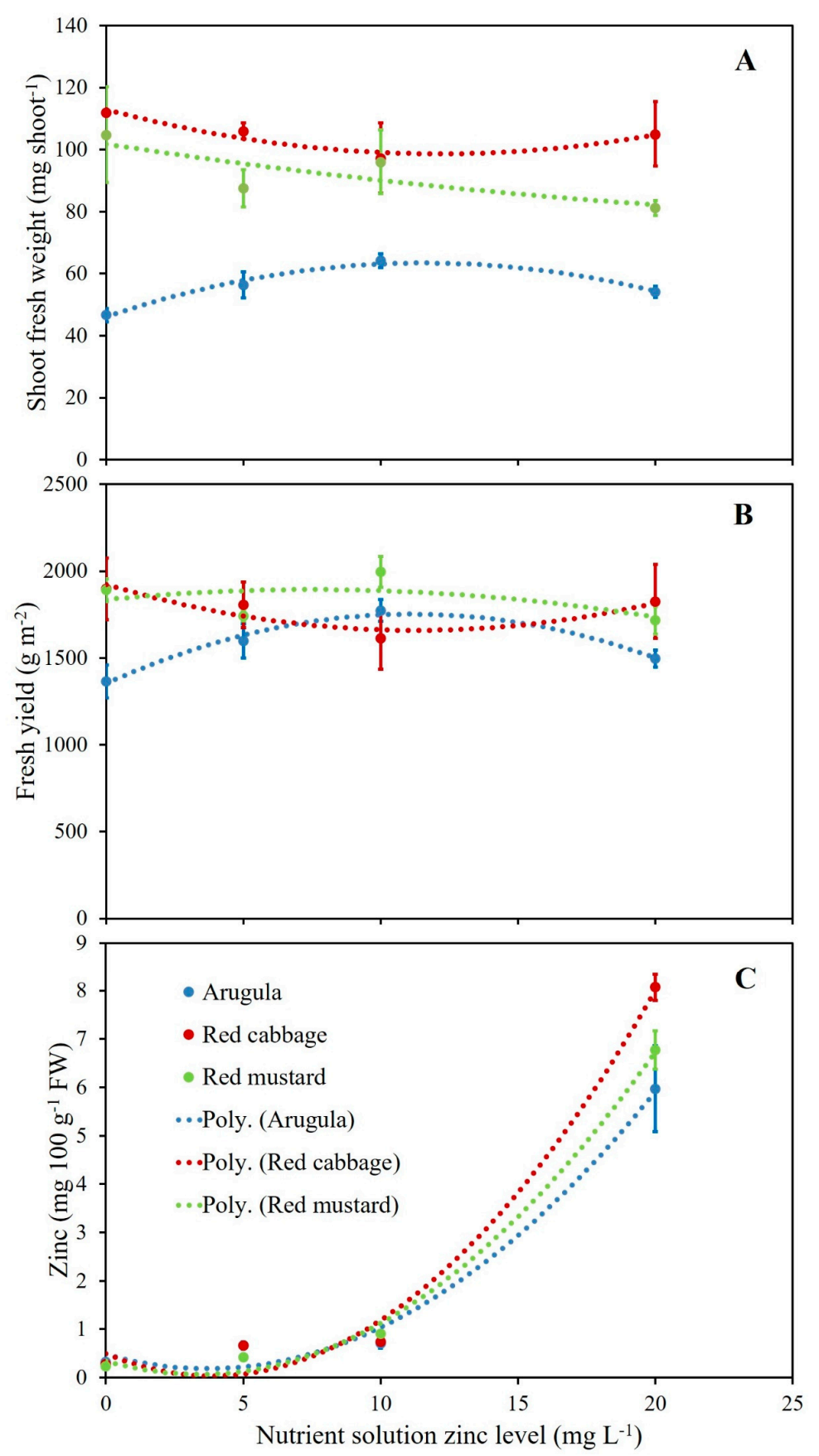

Figure 1. Relationship between single shoot fresh weight (A), fresh yield (B), zinc plant tissue concentration (C) and nutrient solution zinc concentration for arugula, red cabbage, and red mustard. Equations and coefficient of determination $\left(R^{2}\right)$ are reported in Table S1. 
Table 1. Nutrient solution zinc ( $\mathrm{Zn}$ ) level effects on shoot population density, fresh yield, mean single shoot fresh weight, and dry matter accumulation of arugula, red cabbage, and red mustard microgreens ${ }^{1}$.

\begin{tabular}{|c|c|c|c|c|}
\hline Treatments & $\begin{array}{c}\text { Shoot Population } \\
\text { Density } \\
\left(\text { shoot } \mathrm{m}^{-2}\right)\end{array}$ & $\begin{array}{l}\text { Fresh } \\
\text { Yield } \\
\left(\mathrm{g} \mathrm{m}^{-2}\right)\end{array}$ & $\begin{array}{l}\text { Shoot } \\
\text { Fresh Weight } \\
\left(\text { mg shoot }^{-1}\right)\end{array}$ & $\begin{array}{c}\text { Dry } \\
\text { Matter } \\
\left(\mathrm{g} 100 \mathrm{~g}^{-1} \mathrm{FW}\right)\end{array}$ \\
\hline \multicolumn{5}{|l|}{$\mathrm{Zn}\left(\mathrm{mg} \mathrm{L}^{-1}\right)$} \\
\hline 0 & 22,060 & 1718 & 87.81 & 6.36 \\
\hline 5 & 23,384 & 1716 & 83.29 & 6.42 \\
\hline 10 & 21,363 & 1794 & 85.83 & 6.25 \\
\hline 20 & 23,089 & 1679 & 80.13 & 6.56 \\
\hline \multicolumn{5}{|l|}{ Specie (S) } \\
\hline Arugula & 25,697 a & $1558 \mathrm{~b}$ & $55.32 \mathrm{c}$ & $6.37 \mathrm{~b}$ \\
\hline Red cabbage & $19,125 \mathrm{c}$ & $1786 \mathrm{a}$ & $105.08 \mathrm{a}$ & $6.95 \mathrm{a}$ \\
\hline Red mustard & $22,599 \mathrm{~b}$ & 1837 a & $92.40 \mathrm{~b}$ & $5.87 \mathrm{c}$ \\
\hline \multicolumn{5}{|l|}{ pvalue } \\
\hline $\mathrm{Zn}$ & 0.31 & 0.57 & 0.80 & 0.45 \\
\hline$S$ & 0.0001 & 0.02 & 0.0001 & 0.0003 \\
\hline $\mathrm{Zn} \times \mathrm{S}$ & 0.71 & 0.19 & 0.13 & 0.45 \\
\hline
\end{tabular}

${ }^{1} \overline{\text { Values presented are the average of three replications. Means followed by different letters within each column are }}$ significantly different $(p<0.05)$ using Student-Newman-Keuls multiple range test.

\subsection{Microgreens Nutrient Accumulation Response to Zinc (Zn) Enrichment}

Based on regression analysis, it was determined that nutrient accumulation response to increasing levels of $\mathrm{Zn}$ in the nutrient solution was, in general, quadratic except for the case of $\mathrm{K}$ in arugula and $\mathrm{K}$ and Fe in red mustard, which showed a linear response (Table S1). In the case of the $\mathrm{Zn}$ accumulation response to $\mathrm{Zn}$ level, the quadratic coefficient was significant for all three species and the intercept was not significantly different from zero, and the good fit of the quadratic model was confirmed by high $R^{2}$ values observed: 0.92, 0.98, 0.98 for arugula, red cabbage, and red mustard, respectively (Figure 1C). A significant quadratic coefficient was observed also in the case of $\mathrm{Ca}$ and $\mathrm{Mg}$ in arugula and in the case of $\mathrm{P}$ and $\mathrm{Cu}$ in red mustard. Excluding these cases, the nutrient accumulation response to increasing $\mathrm{Zn}$ level in the nutrient solution had low quadratic coefficients and relatively low $R^{2}$, suggesting that the effect of increasing $\mathrm{Zn}$ levels on the accumulation of other nutrients in the shoots of the microgreens tested was weak.

The effect of Zn enrichment and species on mineral content based on the ANOVA is presented in Table 2, where a varied response was observed. For most of the detected minerals, no significant interactions between the tested factors (Zn level and species) were recorded (only in the case of $\mathrm{P}$ and $Z n$ content), while the main effects were significant in most cases (except for the effect of $Z n$ enrichment on $\mathrm{K}$ and $\mathrm{P}$ content). Interestingly, Ca content increased when high $\mathrm{Zn}$ levels were applied in the nutrient solution $\left(>5 \mathrm{mg} \mathrm{L}^{-1}\right.$ ), while in terms of the species effect, red cabbage had the highest $\mathrm{Ca}$ content regardless of the $\mathrm{Zn}$ level. Similar trends were observed for $\mathrm{Mg}$ content although its content did not differ significantly between $\mathrm{Zn}$ levels lower than $20 \mathrm{mg} \mathrm{L}^{-1}$. K content was not affected by Zn enrichment since only the species effect was significant, with arugula and red mustard having the highest values. $\mathrm{P}$ and Fe content was the highest for red cabbage, whereas the effect of $\mathrm{Zn}$ enrichment was significant only for Fe content, where the highest values were recorded for the control treatment $\left(0 \mathrm{mg} \mathrm{L}^{-1}\right)$ without being significantly different from the levels of 5 and $10 \mathrm{mg} \mathrm{L}^{-1}$. In the case of $\mathrm{Cu}$, both factors affected its content in the shoots, with the highest accumulation being detected when $20 \mathrm{mg} \mathrm{L}^{-1}$ of $\mathrm{Zn}$ were added in the nutrient solution, as well as in the shoots of arugula and red mustard. Finally, as expected, the highest $\mathrm{Zn}$ concentration was recorded at the highest level of $\mathrm{Zn}$ application $\left(20 \mathrm{mg} \mathrm{L}^{-1}\right)$ without significant differences between the studied species, although a significant interaction was observed suggesting that the response to $\mathrm{Zn}$ was influenced by the 
species. According to the literature, antagonistic effects between $\mathrm{Zn}$ and $\mathrm{K}, \mathrm{Ca}$, and $\mathrm{Na}$ or $\mathrm{Zn}$ and $\mathrm{Cu}$ and Fe are commonly detected, since they share the same plasma membrane transporters (P3A-type H-ATPases and P1B-Zn-ATPases, respectively) [74]. However, most of the reports refer to soil and/or foliar applications, which could explain the differences with the results of the current study where $\mathrm{Zn}$ was applied directly through the nutrient solution making it more easily available through $\mathrm{pH}$ adjustment and lack of $\mathrm{Zn}$ adsorption to soil particles [75]. On the other hand, root external cell layers and cell vacuoles may regulate nutrient uptake through influx and efflux transport systems and compartmentalization, which is not possible when nutrients are applied through the foliage [76]. Another reason for the contradictory results would be the short growth cycle of microgreens compared to conventionally cultivated crops which does not allow nutrient imbalances and deficiencies to be expressed within the short time between sowing and harvest, while the absorbed $\mathrm{Zn}$ is transported from roots to shoots at these early growth stages [75].

Table 2. Nutrient solution zinc (Zn) level effects on the concentration (mg $100 \mathrm{~g}^{-1} \mathrm{FW}$ ) of calcium $(\mathrm{Ca})$, potassium $(\mathrm{K})$, magnesium $(\mathrm{Mg})$, phosphorous $(\mathrm{P})$, copper $(\mathrm{Cu})$, iron $(\mathrm{Fe})$, and $\mathrm{Zn}$ in arugula, red cabbage, and red mustard microgreens ${ }^{1}$.

\begin{tabular}{|c|c|c|c|c|c|c|c|}
\hline Treatments & $\mathrm{Ca}$ & $\mathbf{K}$ & $\mathrm{Mg}$ & $\mathbf{P}$ & $\mathrm{Cu}$ & $\mathbf{F e}$ & $\mathrm{Zn}$ \\
\hline $\mathrm{Zn}\left(\mathrm{mg} \mathrm{L}^{-1}\right)$ & \multicolumn{7}{|c|}{$\left(\mathrm{mg} 100 \mathrm{~g}^{-1} \mathrm{FW}\right)$} \\
\hline 0 & $124.78 \mathrm{~b}$ & 361.22 & $43.78 \mathrm{~b}$ & 64.89 & $0.05 \mathrm{~b}$ & $0.52 \mathrm{a}$ & $0.28 \mathrm{~b}$ \\
\hline 5 & $123.11 \mathrm{~b}$ & 332.33 & $43.67 \mathrm{~b}$ & 64.22 & $0.05 \mathrm{~b}$ & $0.44 \mathrm{ab}$ & $0.58 \mathrm{~b}$ \\
\hline 10 & $135.00 \mathrm{a}$ & 348.44 & $46.44 \mathrm{ab}$ & 64.56 & $0.05 b$ & $0.44 \mathrm{ab}$ & $0.79 \mathrm{~b}$ \\
\hline 20 & $142.22 \mathrm{a}$ & 355.56 & $49.22 \mathrm{a}$ & 67.44 & $0.07 \mathrm{a}$ & $0.35 \mathrm{~b}$ & $6.94 \mathrm{a}$ \\
\hline \multicolumn{8}{|l|}{ Species (S) } \\
\hline Arugula & $113.75 \mathrm{~b}$ & $374.08 \mathrm{a}$ & $36.75 \mathrm{~b}$ & $65.17 \mathrm{~b}$ & $0.07 \mathrm{a}$ & $0.42 \mathrm{~b}$ & 1.91 \\
\hline Red cabbage & $171.00 \mathrm{a}$ & $301.50 \mathrm{~b}$ & $62.25 \mathrm{a}$ & $69.33 \mathrm{a}$ & $0.04 \mathrm{~b}$ & $0.53 \mathrm{a}$ & 2.44 \\
\hline Red mustard & $109.08 \mathrm{~b}$ & $372.58 \mathrm{a}$ & $38.33 \mathrm{~b}$ & $61.33 c$ & $0.06 \mathrm{a}$ & $0.35 \mathrm{c}$ & 2.08 \\
\hline \multicolumn{8}{|l|}{$p$ value } \\
\hline $\mathrm{Zn}$ & 0.01 & 0.72 & 0.01 & 0.38 & 0.02 & 0.01 & 0.0001 \\
\hline $\mathrm{S}$ & 0.0001 & 0.003 & 0.0001 & 0.00 & 0.00 & 0.0001 & 0.06 \\
\hline $\mathrm{Zn} \times \mathrm{S}$ & 0.25 & 0.37 & 0.12 & 0.03 & 0.52 & 0.23 & 0.02 \\
\hline
\end{tabular}

${ }^{1}$ Values presented are the average of three replications. Means followed by different letters within each column are significantly different $(p<0.05)$ using Student-Newman-Keuls multiple range test.

Considering the significant interactions between the tested factors ( $\mathrm{Zn}$ level and species), $\mathrm{Zn}$ accumulation in the shoots of the tested microgreens in relation to $\mathrm{Zn}$ application is presented in Figure 2. The results for the highest level of $20 \mathrm{mg} \mathrm{L}^{-1}$ of $\mathrm{Zn}$ presented in Table 2 are not presented in this figure since $\mathrm{Zn}$ content in shoots reached levels that could be potentially toxic for consumers. It is clearly shown in Figure 2 that increasing the levels of the applied $\mathrm{Zn}$ resulted in an increase of $\mathrm{Zn}$ content in the shoots of all the tested species, except for the case of red mustard, where $\mathrm{Zn}$ content of shoots increased significantly only when more than $5 \mathrm{mg} \mathrm{L}^{-1}$ of $\mathrm{Zn}$ were added in the nutrient solution. Moreover, when excluding the highest level of the applied $\mathrm{Zn}$, significant differences were observed between the studied species indicating a genotype dependent response to $\mathrm{Zn}$ addition. This finding is of major importance in order to define the safe limits where $\mathrm{Zn}$ enrichment is beneficial through the biofortification of the produced microgreens without exceeding toxicity levels for both plants and the consumers.

The recommended daily allowance (RDA) for zinc is estimated to range between 2 and $5 \mathrm{mg}$ for infants and pre-school children and up to $8-11 \mathrm{mg}$ per day for adult females and males, respectively [14,77]. Therefore, it becomes obvious from our results that the consumption of the tested microgreens can cover only a small percentage of daily requirements, especially for adults, and other complementary zinc sources have to be included in the human diet to achieve $100 \%$ of the RDA. 
However, Zn uptake by roots may vary depending on the genotype and the growing conditions [75]; therefore, further studies are required with more species and/or cultivars of the same species under variable growing conditions to define the best practice guidelines for $\mathrm{Zn}$ biofortification. Moreover, further research is required to estimate $\mathrm{Zn}$ bioavailability in biofortified microgreens.

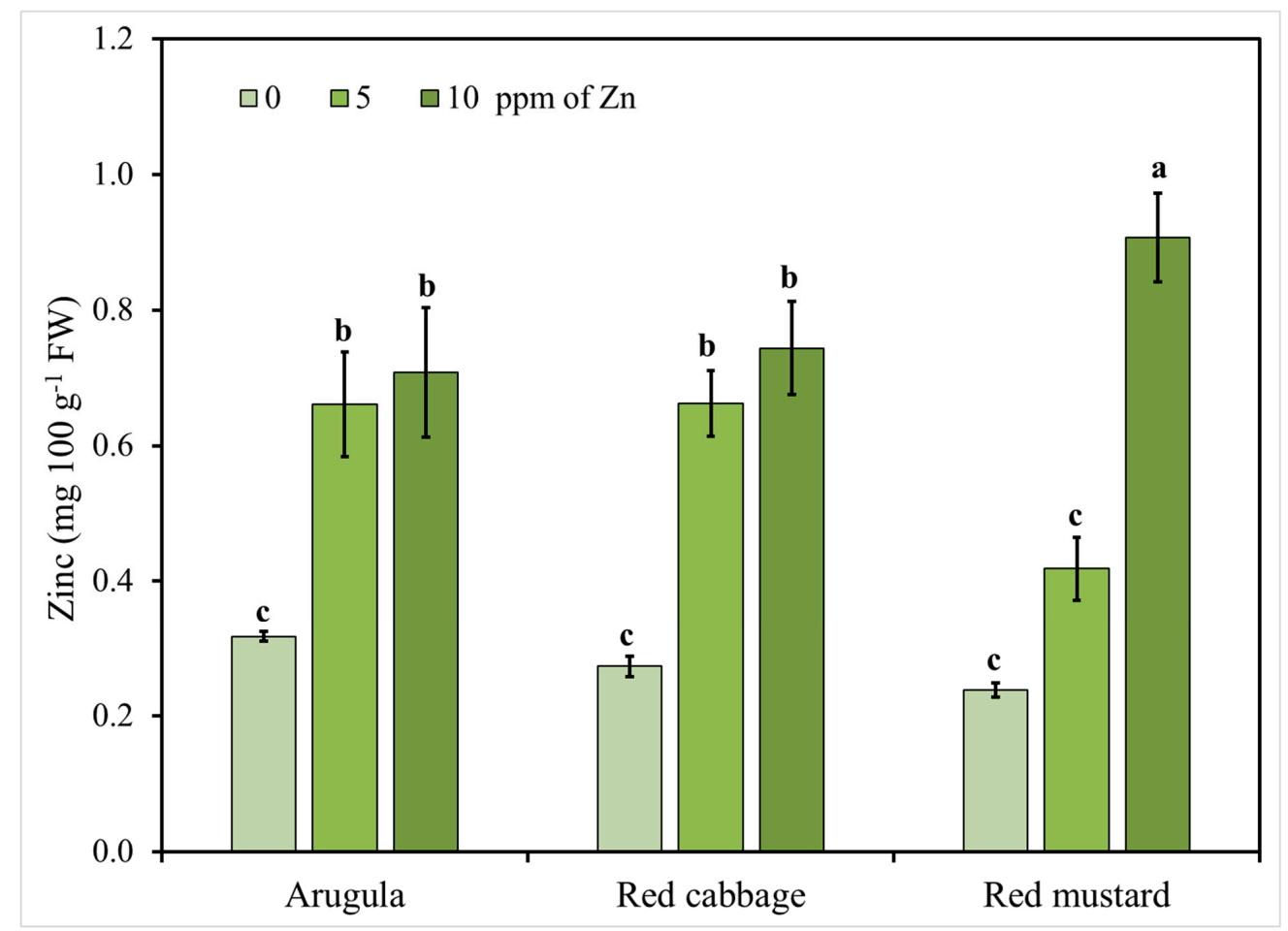

Figure 2. Arugula, red cabbage, and red mustard microgreens zinc ( $\mathrm{Zn})$ concentration in response to nutrient solution $\mathrm{Zn}$ level $\left(0,5,10 \mathrm{mg} \mathrm{L}^{-1}\right)$. Vertical bars represent the mean $\pm \mathrm{SE}$ of three replications. Different letters indicate means that are significantly different $(p<0.05)$ using Student-Newman-Keuls multiple range test.

\subsection{Microgreens Biometric Response to Iron (Fe) Enrichment}

Examining the shoot density, fresh yield, single-shoot fresh weight, and dry matter content response to increasing levels of Fe in the nutrient solution through regression analysis, it was observed that a quadratic model had the best fit for all of the parameters examined in all three species as demonstrated by the relatively high $R^{2}$ values that ranged between 0.72 and 0.98 (Figure 3 and Table S2). Intercepts were always significantly different from zero and the quadratic coefficient was always significant except for fresh yield and shoot fresh weight in red cabbage and shoot fresh weight and dry matter content in arugula. Quadratic coefficients were all negative except for the shoot fresh weight of red cabbage. Such results suggest significant variations of the biometric parameters in response to the level of Fe in the nutrient solution. Variations in shoot fresh weight and fresh yield in response to Fe level are presented in Figure 3A,B, respectively, and clearly show the phytotoxic effect of Fe at the highest level. 

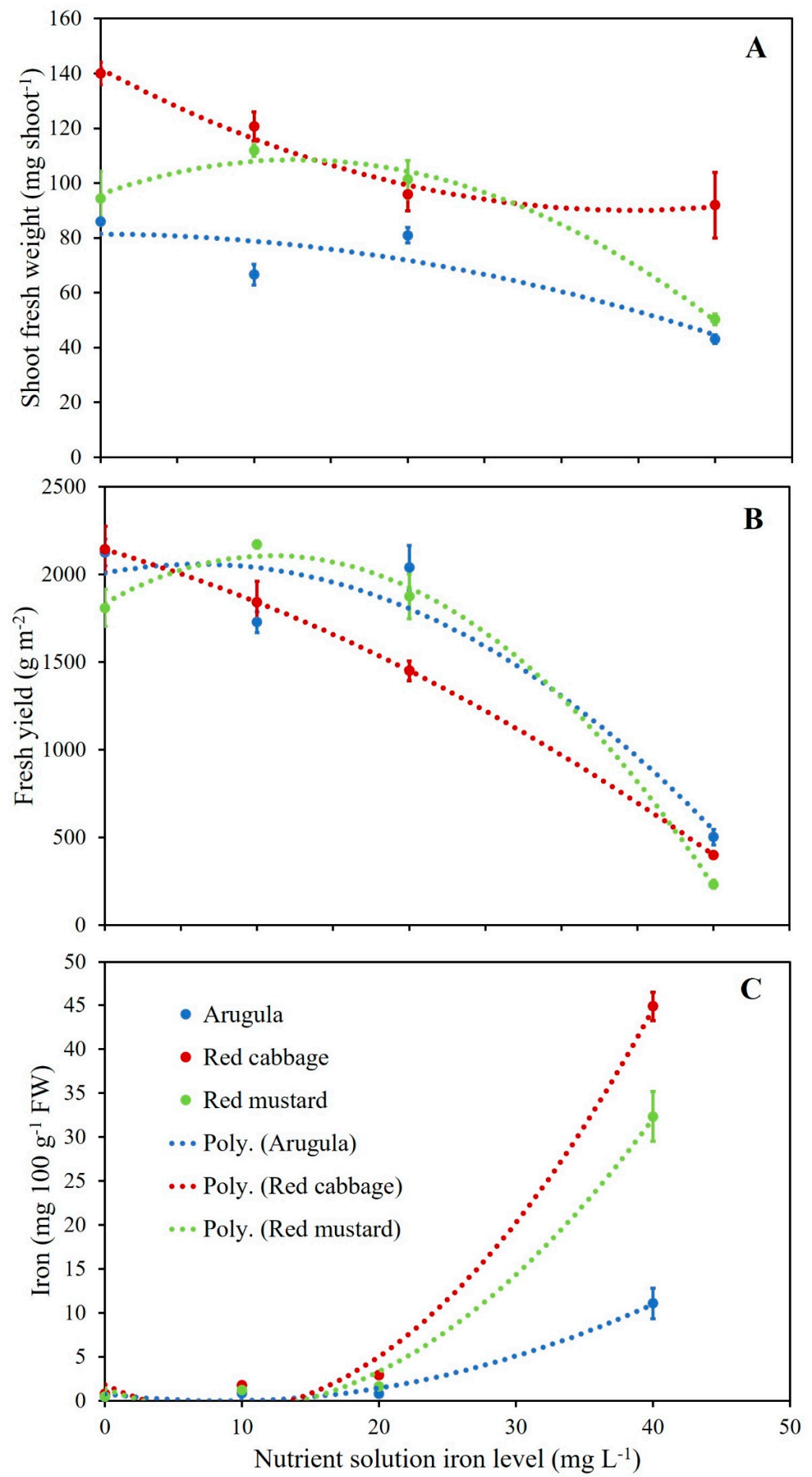

Figure 3. Relationship between single shoot fresh weight (A), fresh yield (B), iron plant tissue concentration (C) and nutrient solution iron concentration for arugula, red cabbage, and red mustard. Equations and coefficient of determination $\left(R^{2}\right)$ are reported in Table S2.

Consistent with the regression analysis, the two-way ANOVA revealed that the Fe addition in the nutrient solution and the species had a significant effect on plant growth parameters (shoot population density, fresh yield, shoot fresh weight, and dry matter content), while a significant interaction between the studied factors (Fe level and species) was also observed (Table 3). In particular, the highest shoot population density was observed in the case of arugula when Fe addition was between 0 and $10 \mathrm{mg} \mathrm{L}^{-1}$. Fresh yield (expressed in $\mathrm{g}$ of harvested tissue per $\mathrm{m}^{2}$ ) was higher when no Fe (in the case of arugula 
and red cabbage) or $10 \mathrm{mg} \mathrm{L}^{-1}$ (in the case of red mustard) were added. It is important to point out that the addition of high levels of Fe seemed to be toxic for the tested species, since both shoot population density and fresh yield were the lowest for this level for all the tested species. Similarly, in terms of shoot fresh weight (expressed in mg of fresh weight per shoot), Fe enrichment was not beneficial when applied at high concentrations $\left(40 \mathrm{mg} \mathrm{L}^{-1}\right)$, while the highest values were recorded in red cabbage when no Fe was added in the nutrient solution (control treatment). The phytotoxic effect of the highest Fe level $\left(40 \mathrm{mg} \mathrm{L}^{-1}\right)$ was observed visually on all three species immediately after germination due to a lower seed germination and stunting of plants, which would be considered unmarketable. Finally, dry matter (DM) content values confirm the negative effects of the addition of high Fe levels in the nutrient solution, since although $\mathrm{Fe}$ is a key element for plant growth and physiological processes, it is also involved in the production of reactive oxygen species and consequently to oxidative stress through the Fenton reaction [78]. Similarly, Przybysz et al. [41] reported a negative impact on fresh yield of broccoli and radish sprouts enriched with Fe at concentrations of 24 and $36 \mathrm{mg} \mathrm{L}^{-1}$, while no negative effects were observed on alfalfa and mung bean sprouts, suggesting that the response to increasing levels of Fe may vary significantly between species. Giordano et al. have also reported negative effects of high levels of $\mathrm{Fe}(2 \mathrm{mM} \mathrm{Fe})$ in nutrient solution on plant growth and yield parameters of hydroponically grown lettuce [79]. According to Fihlo et al., Fe levels higher than $25 \mathrm{mg} \mathrm{L}^{-1}$ caused toxicity symptoms in hydroponically grown common chicory (Cichorium intybus), although the toxicity threshold may vary among species $[80,81]$.

Table 3. Nutrient solution iron $(\mathrm{Fe})$ level effects on shoot population density, fresh yield, mean single shoot fresh weight, and dry matter accumulation of arugula, red cabbage, and red mustard microgreens ${ }^{1}$.

\begin{tabular}{|c|c|c|c|c|c|}
\hline Species (S) & $\begin{array}{c}\mathrm{Fe} \\
\left(\mathrm{mg} \mathrm{L}^{-1}\right)\end{array}$ & $\begin{array}{l}\text { Shoot Population Density } \\
{\text { (shoot } \mathrm{m}^{-2} \text { ) }}\end{array}$ & $\begin{array}{l}\text { Fresh Yield } \\
\qquad\left(\mathrm{g} \mathrm{m}^{-2}\right)\end{array}$ & $\begin{array}{l}\text { Shoot Fresh Weight } \\
\quad\left(\mathrm{mg} \mathrm{shoot}^{-1}\right)\end{array}$ & $\begin{array}{c}\text { Dry Matter } \\
\left(\mathrm{g} 100 \mathrm{~g}^{-1} \mathrm{FW}\right)\end{array}$ \\
\hline \multirow[t]{4}{*}{ Arugula } & 0 & $29,582 \mathrm{a}$ & $2125 \mathrm{a}$ & 86.0 de & $5.61 \mathrm{e}$ \\
\hline & 10 & $28,775 \mathrm{a}$ & $1728 \mathrm{~b}$ & $66.6 \mathrm{ef}$ & $6.37 \mathrm{e}$ \\
\hline & 20 & 24,968 b & $2039 a b$ & 80.9 de & $5.59 \mathrm{e}$ \\
\hline & 40 & $13,520 \mathrm{f}$ & $503 \mathrm{~d}$ & $43.1 \mathrm{~g}$ & $9.56 \mathrm{c}$ \\
\hline \multirow[t]{4}{*}{ Red cabbage } & 0 & 17,778 def & $2142 \mathrm{a}$ & $140.0 \mathrm{a}$ & $6.69 \mathrm{e}$ \\
\hline & 10 & 16,861 ef & $1842 \mathrm{ab}$ & $120.7 \mathrm{~b}$ & $7.33 \mathrm{de}$ \\
\hline & 20 & 16,961 ef & $1451 \mathrm{c}$ & $95.8 \mathrm{~cd}$ & $8.53 \mathrm{~cd}$ \\
\hline & 40 & $5740 \mathrm{~g}$ & $400 \mathrm{~d}$ & $91.9 \mathrm{~cd}$ & $19.32 \mathrm{a}$ \\
\hline \multirow[t]{4}{*}{ Red mustard } & 0 & $22,738 \mathrm{bc}$ & $1810 \mathrm{ab}$ & $94.4 \mathrm{~cd}$ & $6.56 \mathrm{e}$ \\
\hline & 10 & $22,033 \mathrm{bcd}$ & $2171 \mathrm{a}$ & $112.0 \mathrm{bc}$ & $5.76 \mathrm{e}$ \\
\hline & 20 & 20,113 cde & $1875 \mathrm{ab}$ & $101.3 \mathrm{bcd}$ & $6.13 \mathrm{e}$ \\
\hline & 40 & $4484 \mathrm{~g}$ & $234 \mathrm{~d}$ & $50.3 \mathrm{fg}$ & $14.10 \mathrm{~b}$ \\
\hline \multicolumn{6}{|l|}{ p value } \\
\hline $\mathrm{Fe}$ & & 0.0001 & 0.0001 & 0.0001 & 0.0001 \\
\hline$S$ & & 0.0001 & 0.0001 & 0.0001 & 0.0001 \\
\hline $\mathrm{Fe} \times \mathrm{S}$ & & 0.10 & 0.001 & 0.004 & 0.0001 \\
\hline
\end{tabular}

${ }^{1}$ Values presented are the average of three replications. Means followed by different letters within each column are significantly different $(p<0.05)$ using Student-Newman-Keuls multiple range test.

\subsection{Microgreens Nutrient Accumulation Response to Iron (Fe) Enrichment}

The nutrient accumulation response to increasing levels of Fe in the nutrient solution was quadratic in most cases except for $\mathrm{K}$ in red mustard and $\mathrm{Zn}$ for all three species, which showed a linear increase with increasing Fe level as suggested by the positive slope values (Table S2). Excluding the relationship that responded well to a linear model, the quadratic model was a good fit as demonstrated by the significant quadratic coefficient and the relatively high $R^{2}$ values, with the exception of $\mathrm{Ca}, \mathrm{K}, \mathrm{Mg}$, and $\mathrm{Cu}$ in arugula for which the quadratic coefficient was not significant and $R^{2}$ values were relatively low. The level of $\mathrm{Fe}$ in the nutrient solution significantly impacted the accumulation of other nutrients, with different interactions depending on the species examined. In the case of the Fe accumulation response to Fe level in the nutrient solution, the quadratic coefficient and the slope were significant for all three 
species except for the slope of arugula, and the intercept was not significantly different from zero for all three species. $R^{2}$ values ranging from 0.91 to 0.99 confirmed the good fit of the quadratic model for all three species (Figure 3C).

On the basis of the two-way ANOVA, mineral content in the shoots of the studied species was significantly affected by both tested factors (Fe level and species), while significant interactions between these factors were also observed for all the assayed minerals (Table 4). The enrichment of the nutrient solution with the highest concentration of $\mathrm{Fe}\left(40 \mathrm{mg} \mathrm{L}^{-1}\right)$ had a positive effect for all the assayed minerals in the case of red cabbage, except for the case of $\mathrm{K}$ content where the highest values were recorded in red mustard for the same Fe enrichment level. However, considering that DM content had the highest values at the same Fe enrichment level and the same species (see Table 3), it could be assumed that the observed mineral content could be the result of a concentration effect. As expected, Fe content in the plant tissues increased with increasing application rates and up to $11.07 \mathrm{mg} \mathrm{L}^{-1}$, $44.85 \mathrm{mg} \mathrm{L}^{-1}$, and $32.33 \mathrm{mg} \mathrm{L}^{-1}$ for arugula, red cabbbage, and red mustard, respectively. In the study of Giordano et al., the addition of $2 \mathrm{mM}$ of Fe in the nutrient solution resulted in increased Fe content in the leaves of lettuce, regardless of the genotype [79]. However, in the same study, a negative effect of high Fe levels was observed on $\mathrm{Ca}, \mathrm{K}$, and $\mathrm{Mg}$ content in lettuce leaves, which was attributed to competition effects among the cations as well as to root injury and oxidative stress [79]. In contrast to the current study, Przybysz et al. did not observe a significant effect of Fe enrichment (up to $36 \mathrm{mg} \mathrm{L}^{-1}$ ) on $\mathrm{Mg}, \mathrm{Ca}, \mathrm{K}, \mathrm{Zn}$, and $\mathrm{Mn}$ content in broccoli sprouts, while a varied effect was recorded on $\mathrm{Zn}$ content in radish sprouts [41]. Another implication from the application of high levels of Fe is that it may also increase the accumulation of antinutritional nitrates, as pointed out in the literature for Swiss chard shoots [82]. This could be critical to assess, especially if biofortified microgreens are designed to supplement the diet of infants and pre-school children, because high levels of nitrates could be detrimental for their health causing methemoglobinemia $[83,84]$ and considering that, like other leafy vegetables, microgreens can accumulate relatively high levels of nitrates $[58,85,86]$.

Table 4. Nutrient solution iron (Fe) level effects on the concentration (mg $100 \mathrm{~g}^{-1} \mathrm{FW}$ ) of calcium (Ca), potassium $(\mathrm{K})$, magnesium $(\mathrm{Mg})$, phosphorous $(\mathrm{P})$, copper $(\mathrm{Cu}), \mathrm{Fe}$, and zinc $(\mathrm{Zn})$ in arugula, red cabbage, and red mustard microgreens ${ }^{1}$.

\begin{tabular}{|c|c|c|c|c|c|c|c|c|}
\hline Species (S) & $\begin{array}{c}\mathrm{Fe} \\
\left(\mathrm{mg} \mathrm{L}^{-1}\right)\end{array}$ & \multicolumn{7}{|c|}{$\left(\mathrm{mg} 100 \mathrm{~g}^{-1} \mathrm{FW}\right)$} \\
\hline \multirow[t]{4}{*}{ Arugula } & 0 & $119.41 \mathrm{~d}$ & 398.16 bc & $38.16 \mathrm{f}$ & $56.80 \mathrm{~d}$ & $0.06 \mathrm{c}$ & $0.49 \mathrm{~d}$ & $0.28 \mathrm{e}$ \\
\hline & 10 & $124.73 \mathrm{~d}$ & 344.53 cde & 43.26 ef & $52.37 \mathrm{~d}$ & $0.07 \mathrm{c}$ & $0.83 \mathrm{~d}$ & $0.41 \mathrm{e}$ \\
\hline & 20 & $119.40 \mathrm{~d}$ & $452.23 \mathrm{~b}$ & 41.26 ef & $58.21 \mathrm{~d}$ & $0.06 \mathrm{c}$ & $0.81 \mathrm{~d}$ & $0.56 \mathrm{de}$ \\
\hline & 40 & $150.21 \mathrm{~d}$ & $427.07 \mathrm{bc}$ & $56.99 \mathrm{e}$ & $120.81 \mathrm{c}$ & $0.13 \mathrm{bc}$ & $11.07 \mathrm{c}$ & $0.92 \mathrm{c}$ \\
\hline \multirow[t]{4}{*}{ Red cabbage } & 0 & 184.02 c & 297.77 de & $69.52 \mathrm{~d}$ & $54.83 \mathrm{~d}$ & $0.10 \mathrm{c}$ & $0.77 \mathrm{~d}$ & $0.32 \mathrm{e}$ \\
\hline & 10 & $197.29 \mathrm{c}$ & $307.91 \mathrm{de}$ & $79.91 \mathrm{~cd}$ & $60.41 \mathrm{~d}$ & $0.09 \mathrm{c}$ & $1.74 \mathrm{~d}$ & $0.55 \mathrm{de}$ \\
\hline & 20 & 207.57 c & $260.71 \mathrm{e}$ & 86.14 bc & $64.07 \mathrm{~d}$ & 0.14 bc & $2.90 \mathrm{~d}$ & $1.21 \mathrm{~b}$ \\
\hline & 40 & $326.83 \mathrm{a}$ & $422.61 \mathrm{bc}$ & $134.51 \mathrm{a}$ & $202.09 \mathrm{a}$ & $0.42 \mathrm{a}$ & $44.85 \mathrm{a}$ & $2.53 \mathrm{a}$ \\
\hline \multirow[t]{4}{*}{ Red mustard } & 0 & $128.81 \mathrm{~d}$ & $384.48 \mathrm{bcd}$ & 49.39 ef & $48.10 \mathrm{~d}$ & $0.06 \mathrm{c}$ & $0.49 \mathrm{~d}$ & $0.25 \mathrm{e}$ \\
\hline & 10 & $130.87 \mathrm{~d}$ & $475.06 \mathrm{~b}$ & 47.55 ef & $52.85 \mathrm{~d}$ & $0.07 \mathrm{c}$ & $1.20 \mathrm{~d}$ & $0.41 \mathrm{e}$ \\
\hline & 20 & $134.58 \mathrm{~d}$ & $465.28 \mathrm{~b}$ & $51.05 \mathrm{ef}$ & $52.71 \mathrm{~d}$ & $0.07 \mathrm{c}$ & $1.64 \mathrm{~d}$ & $0.85 \mathrm{~cd}$ \\
\hline & 40 & $239.70 \mathrm{~b}$ & 566.39 a & $93.68 \mathrm{~b}$ & $161.28 \mathrm{~b}$ & $0.18 \mathrm{~b}$ & $32.33 \mathrm{~b}$ & $1.38 \mathrm{~b}$ \\
\hline \multicolumn{9}{|l|}{ p value } \\
\hline $\mathrm{Fe}$ & & 0.0001 & 0.01 & 0.0001 & 0.0001 & 0.0001 & 0.0001 & 0.0001 \\
\hline $\mathrm{S}$ & & 0.0001 & 0.0001 & 0.0001 & 0.0001 & 0.0001 & 0.0001 & 0.0001 \\
\hline $\mathrm{Fe} \times \mathrm{S}$ & & 0.0001 & 0.01 & 0.0004 & 0.0001 & 0.0001 & 0.0001 & 0.0001 \\
\hline
\end{tabular}

${ }^{1}$ Values presented are the average of three replications. Means followed by different letters within each column are significantly different $(p<0.05)$ using Student-Newman-Keuls multiple range test.

Considering the significant interactions between the tested factors (Fe level and species), Fe accumulation in the shoots of the tested microgreens in relation to Fe application is presented 
in Figure 4. Similarly to Zn enrichment, the results for the highest level of $40 \mathrm{mg} \mathrm{L}^{-1}$ of Fe are not presented in this figure since Fe content in shoots reached toxicity levels that could be potentially toxic for consumers and were certainly toxic for the plants. As can be seen in Figure 4, increasing the concentration of $\mathrm{Fe}$ in the nutrient solution resulted in an increased Fe content in the shoots of all the tested species. Moreover, among the three species, red cabbage was the most sensitive to Fe enrichment where almost a $278 \%$ increase in Fe content in shoots was recorded the level of $20 \mathrm{mg} \mathrm{L}^{-1}$ of Fe compared to the control treatment, while Fe content was about three and two times higher than that of arugula and red mustard, respectively, for the same enrichment level. The levels of Fe increase observed in this study for red mustard and especially red cabbage were considerably higher compared to the increments observed by Przybysz et al., ranging from $50 \%$ to $130 \%$ at the highest level of Fe (36 mg L $\left.{ }^{-1}\right)$ in sprouts of broccoli, radish, alfalfa, and mung bean [41]. Such difference, although it could be partially due to a difference in terms of growth cycle length between sprouts and microgreens, further highlights the importance of examining a larger variety of species to identify the ones that are more suitable to Fe biofortification. Differences in Fe content have been also reported between biofortified green and red pigmented lettuce leaves by Giordano et al. and cowpea by Márquez-Quiroz et al., while other factors may also affect the biofortification efficiency including growing conditions and farming practices $[28,41,79,80,87]$. Considering that the RDA for Fe is estimated at $8-18 \mathrm{mg}$ per day for adults older than 18 years old [14,77], the consumption of even small amounts of these three microgreens could help to cover the total daily requirements and they could be considered as useful dietary supplements, especially in the case of pregnant women where RDA of Fe increases to $27 \mathrm{mg}$ per day. However, considering that Fe uptake mechanisms from plants are closely associated with the uptake processes of other metals potentially toxic to human health, further consideration is needed for Fe biofortification [74]. Yet, as for $\mathrm{Zn}$, further research is required to assess the level of Fe bioavailability in biofortified microgreens.

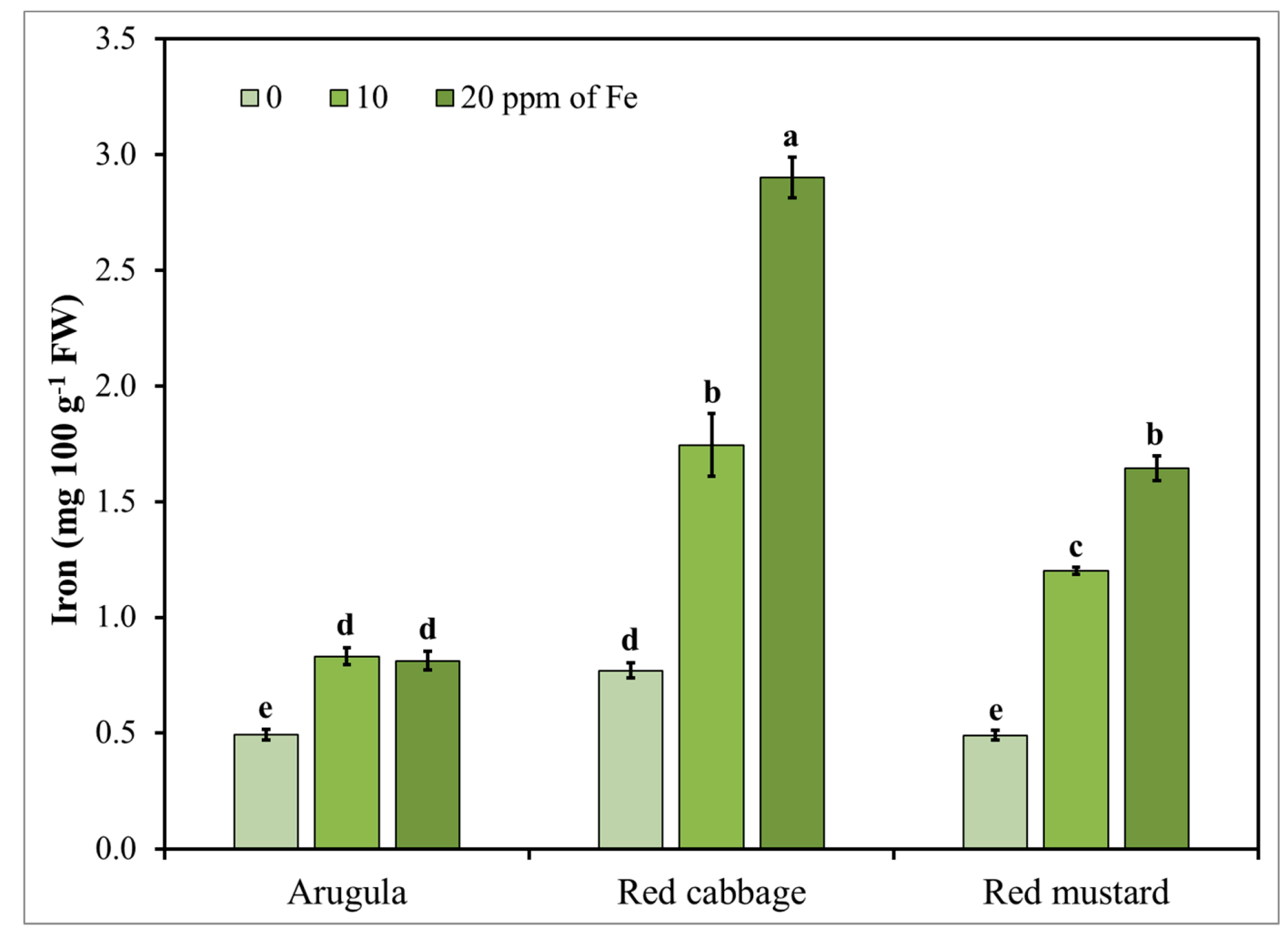

Figure 4. Arugula, red cabbage, and red mustard microgreens iron (Fe) concentration in response to nutrient solution Fe level $\left(0,10,20 \mathrm{mg} \mathrm{L}^{-1}\right)$. Vertical bars represent the mean $\pm \mathrm{SE}$ of three replications. Different letters indicate means that are significantly different $(p<0.05)$ using Student-Newman-Keuls multiple range test. 


\section{Conclusions}

Addressing malnutrition issues such as Fe and Zn deficiency afflicting a large portion of the world population is a big challenge that deserves great attention and dedication in order to enhance the health and life quality of billions of people around the world. While there are no simple solutions to such a complex public health issue, the agronomic biofortification of staple crops and vegetables aimed at artificially enriching their content of essential nutrients has the potential to complement other strategies and contribute to address dietary $\mathrm{Fe}$ and $\mathrm{Zn}$ deficiency providing a relatively quick short-term solution that may be applied to face nutrition security emergencies. The potential success of this strategy relies on the adequate selection of target crops and the optimization and potential standardization of the biofortification process in order to assure the sustainability of the production process and the obtainment of a biofortified product that is of high quality, safe to eat, effective in delivering adequate levels of micronutrients in order to meet the RDA of the specific element, and easy to introduce as a crop or as a food source to the diet of communities affected by malnutrition and often resident in poor regions of the world. In this study, we propose microgreens as a target crop category for Fe and $\mathrm{Zn}$ biofortification. The possibility to self-produce nutrient-dense biofortified microgreens domestically, in a very short time (7-21 days), using only very simple soilless systems with the potential of exploiting a wide variety of species, could contribute to enrich and diversify the diet of malnourished communities in marginal areas of both industrialized and developing countries. By using three Brassicaceae species as test crops, it is demonstrated here that microgreens are a good candidate crop category for Fe and $\mathrm{Zn}$ agronomic biofortification. While genotype specific responses were observed for both Fe and $\mathrm{Zn}$ enrichment, this study allowed for: (i) identification of levels of Fe and $\mathrm{Zn}$ supply through the nutrient solution above which it is possible to observe phytotoxicity and accumulation of Fe and $\mathrm{Zn}$ at toxic levels not safe for human consumption; (ii) establishing levels of Fe and Zn supply that may allow for adequate accumulation levels for both micronutrients without decreasing yield and quality of the microgreens; (iii) identification of species that respond better to both Fe and Zn biofortification. Using a simple NFT (nutrient film technique) soilless growing system, supplementing a standard half-strength Hoagland nutrient solution with $5-10 \mathrm{mg} \mathrm{L}^{-1}$ of $\mathrm{Zn}\left(\mathrm{ZnSO}_{4}\right)$ allowed an increase in the concentration in microgreen tissue from a minimum of $75 \%$ to a maximum of $281 \%$, the level observed in microgreens grown with a standard nutrient solution without any yield or quality reduction. Similarly, supplementing the standard nutrient solution with $10-20 \mathrm{mg} \mathrm{L}^{-1}$ of Fe allowed an increase in Fe concentration in the microgreens shoots ranging from $64 \%$ to $278 \%$, the level observed in the untreated control, with no or only small negative impacts on fresh yield. It is concluded that Brassicaceae microgreens grown in a NFT soilless system are a good candidate crop for $\mathrm{Zn}$ and Fe agronomic biofortification through the simple regulation of $\mathrm{Fe}$ and $\mathrm{Zn}$ concentration in the nutrient solution. Further investigations should be conducted to optimize the biofortification method and (i) explore the suitability of Fe and $\mathrm{Zn}$ biofortification of other microgreens species and cultivars; (ii) assess the potential presence of antinutritional (phytates, nitrates, accumulation of toxic metals) or pro-absorption factors (ascorbic acid, $\beta$-carotene) in $\mathrm{Zn}$ and Fe biofortified microgreens; and (iii) assess the bioavailability and bioaccessibility of both Fe and Zn biofortified microgreens.

Supplementary Materials: The following are available online at http://www.mdpi.com/2073-4395/9/11/677/s1, Table S1: Parameter estimates, significance, $R^{2}$, and equation of linear and quadratic response of examined biometric parameters and mineral concentration to nutrient solution zinc concentration in arugula, red cabbage, and red mustard, Table S2: Parameter estimates, significance, $R^{2}$ and equation of linear and quadratic response of examined biometric parameters and mineral concentration to nutrient solution iron (Fe) concentration in arugula, red cabbage, and red mustard.

Author Contributions: F.D.G. developed the idea, defined the experimental protocol, coordinated the research and carried out the experiment, performed statistical analyses, and prepared the first draft of the manuscript. S.A.P. was significantly involved in data interpretation and manuscript writing and contributed in improving the final version of the manuscript. M.O.-H. provided resources necessary to conduct the experiment and contributed to the definition of the experimental protocol. K.M. provided resources necessary to conduct the experiment and coordinated ICP analyses and data quality and manuscript revision. E.N.R. provided resources necessary to 
conduct the experiment, contributed to defining procedures for statistical analysis, contributed in improving the final version of the manuscript, and manuscript review.

Funding: This work was supported by the USDA National Institute of Food and Agriculture and Hatch Appropriations under Project \#PEN04723 and Accession \#1020664.

Acknowledgments: The authors wish to thank Kamal Mahmoud for the assistance in performing the mineral analysis, Joel Mendez, Roger McGill, John Dunckelman, Alisheikh Atta, Gilma Castillo, and Thaisa Cantele for their technical assistance, and Seedway for providing the seeds used in this study.

Conflicts of Interest: The authors declare no conflict of interest.

\section{References}

1. McLean, E.; Cogswell, M.; Egli, I.; Wojdyla, D.; De Benoist, B. Worldwide prevalence of anaemia, WHO Vitamin and Mineral Nutrition Information System, 1993-2005. Public Health Nutr. 2009, 12, $444-454$. [CrossRef] [PubMed]

2. Wessells, K.R.; Brown, K.H. Estimating the Global Prevalence of Zinc Deficiency: Results Based on Zinc Availability in National Food Supplies and the Prevalence of Stunting. PLoS ONE 2012, 7, e50568. [CrossRef] [PubMed]

3. Miller, B.D.D.; Welch, R.M. Food system strategies for preventing micronutrient malnutrition. Food Policy 2013, 42, 115-128. [CrossRef]

4. Clemens, S. Zn and Fe biofortification: The right chemical environment for human bioavailability. Plant Sci. 2014, 225, 52-57. [CrossRef] [PubMed]

5. Fraga, C.G. Relevance, essentiality and toxicity of trace elements in human health. Mol. Aspects Med. 2005, 26, 235-244. [CrossRef] [PubMed]

6. Bharadva, K.; Mishra, S.; Tiwari, S.; Yadav, B.; Deshmukh, U.; Elizabeth, K.E.; Banapurmath, C.R. Prevention of Micronutrient Deficiencies in Young Children: Consensus Statement from Infant and Young Child Feeding Chapter of Indian Academy of Pediatrics. Indian Pediatr. 2019, 56, 577-586. [CrossRef]

7. Black, R.E.; Allen, L.H.; Bhutta, Z.A.; Caulfield, L.E.; de Onis, M.; Ezzati, M.; Mathers, C.; Rivera, J. Maternal and child undernutrition: Global and regional exposures and health consequences. Lancet 2008, 371, 243-260. [CrossRef]

8. Oteiza, P.I.; Mackenzie, G.G. Zinc, oxidant-triggered cell signaling, and human health. Mol. Aspects Med. 2005, 26, 245-255. [CrossRef]

9. Johnson, F.; Giulivi, C. Superoxide dismutases and their impact upon human health. Mol. Aspects Med. 2005, 26, 340-352. [CrossRef]

10. Hotz, C.; Brown, K.H. Contents International Zinc Nutrition Consultative Group (IZiNCG) Technical Document. Food Nutr. Bull. 2004, 25, S94-S200.

11. Plum, L.M.; Rink, L.; Hajo, H. The essential toxin: Impact of zinc on human health. Int. J. Environ. Res. Public Health 2010, 7, 1342-1365. [CrossRef] [PubMed]

12. Cakmak, I. Enrichment of cereal grains with zinc: Agronomic or genetic biofortification? Plant Soil 2008, 302, 1-17. [CrossRef]

13. St. Clair, S.B.S.; Lynch, J.P. The opening of Pandora's Box: Climate change impacts on soil fertility and crop nutrition in developing countries. Plant Soil 2010, 335, 101-115. [CrossRef]

14. White, P.J.; Broadley, M.R. Biofortifying crops with essential mineral elements. Trends Plant Sci. 2005, 10, 586-593. [CrossRef] [PubMed]

15. García-Casal, M.N. Planning and Implementing Food Fortification Programs to Combat Micronutrient Malnutrition: Iron. Food Nutr. Sci. 2014, 5, 880-888. [CrossRef]

16. Murgia, I.; Arosio, P.; Tarantino, D.; Soave, C. Biofortification for combating "hidden hunger" for iron. Trends Plant Sci. 2012, 17, 47-55. [CrossRef]

17. Palmgren, M.G.; Clemens, S.; Williams, L.E.; Krämer, U.; Borg, S.; Schjørring, J.K.; Sanders, D. Zinc biofortification of cereals: Problems and solutions. Trends Plant Sci. 2008, 13, 464-473. [CrossRef]

18. White, P.J.; Broadley, M.R. Physiological limits to zinc biofortification of edible crops. Front. Plant Sci. 2011, 2, 1-11. [CrossRef] 
19. Dias, D.M.; de Castro Moreira, M.E.; Gomes, M.J.C.; Toledo, R.C.L.; Nutti, M.R.; Sant'Ana, H.M.P.; Martino, H.S.D. Rice and bean targets for biofortification combined with high carotenoid content crops regulate transcriptional mechanisms increasing iron bioavailability. Nutrients 2015, 7, 9683-9696. [CrossRef]

20. Mukamuhirwa, F.; Tusiime, G.; Mukankusi, M.C. Inheritance of high iron and zinc concentration in selected bean varieties. Euphytica 2015, 205, 349-360. [CrossRef]

21. Kumar, S.; Palve, A.; Joshi, C.; Srivastava, R.K.; Rukhsar. Crop biofortification for iron (Fe), zinc (Zn) and vitamin A with transgenic approaches. Heliyon 2019, 5, e01914. [CrossRef] [PubMed]

22. Corguinha, A.P.B.; Carvalho, C.A.; de Souza, G.A.; de Carvalho, T.S.; Vieira, E.A.; Fialho, J.F.; Guilherme, L.R.G. Potential of cassava clones enriched with $\beta$-carotene and lycopene for zinc biofortification under different soil Zn conditions. J. Sci. Food Agric. 2019, 99, 666-674. [CrossRef] [PubMed]

23. Stein, A.J.; Meenakshi, J.V.; Qaim, M.; Nestel, P.; Sachdev, H.P.S.; Bhutta, Z.A. Potential impacts of iron biofortification in India. Soc. Sci. Med. 2008, 66, 1797-1808. [CrossRef] [PubMed]

24. Zimmermann, M.B.; Hurrell, R.F. Improving iron, zinc and vitamin A nutrition through plant biotechnology. Curr. Opin. Biotechnol. 2002, 13, 142-145. [CrossRef]

25. Bouis, H.E.; Saltzman, A. Improving nutrition through biofortification: A review of evidence from HarvestPlus, 2003 through 2016. Glob. Food Sec. 2017, 12, 49-58. [CrossRef]

26. Sida-Arreola, J.P.; Sánchez-Chávez, E.; Ávila-Quezada, G.D.; Zamudio-Flores, P.B.; Acosta Muñíz, C.H. Iron biofortification and its impact on antioxidant system, yield and biomass in common bean. Plant, Soil Environ. 2015, 61, 573-576.

27. Slamet-loedin, I.H.; Johnson-beebout, S.E.; Impa, S.; Tsakirpaloglou, N. Enriching rice with Zn and Fe while minimizing Cd risk. Front. Plant Sci. 2015, 6, 1-9. [CrossRef]

28. Márquez-Quiroz, C.; De-La-cruz-Lázaro, E.; Osorio-Osorio, R.; Sánchez-Chávez, E. Biofortification of cowpea beans with iron: Iron's influence on mineral content and yield. J. Soil Sci. Plant Nutr. 2015, 15, 839-847. [CrossRef]

29. Wei, Y.; Shohag, M.J.I.; Wang, Y.; Lu, L.; Wu, C.; Yang, X. Effect of zinc sulfate fortification in germinated brown rice on seed zinc concentration, bioavailability, and seed germination. J. Agric. Food Chem. 2012, 60, 1871-1879. [CrossRef]

30. Nilsson, J.; Olsson, K.; Engqvist, G.; Ekvall, J.; Olsson, M.; Nyman, M.; Åkesson, B. Variation in the content of glucosinolates, hydroxycinnamic acids, carotenoids, total antioxidant capacity and low-molecular-weight carbohydrates inBrassica vegetables. J. Sci. Food Agric. 2006, 86, 528-538. [CrossRef]

31. Niyigaba, E.; Twizerimana, A.; Mugenzi, I.; Ngnadong, W.A.; Ye, Y.P.; Wu, B.M.; Hai, J.B. Winter wheat grain quality, zinc and iron concentration affected by a combined foliar spray of zinc and iron fertilizers. Agronomy 2019, 9, 250. [CrossRef]

32. Ning, P.; Wang, S.; Fei, P.; Zhang, X.; Dong, J.; Shi, J.; Tian, X. Enhancing Zinc Accumulation and Bioavailability in Wheat Grains by Integrated Zinc and Pesticide Application. Agronomy 2019, 9, 530. [CrossRef]

33. Dordas, C. Application of calcium and magnesium improves yield and essential oil yield of oregano (Origanum vulgare ssp. hirtum). Ital. J. Agron. 2008, 3, 417-418.

34. Tzortzakis, N.G. Potassium and calcium enrichment alleviate salinity-induced stress in hydroponically grown endives. Hortic. Sci. 2010, 37, 155-162. [CrossRef]

35. Chrysargyris, A.; Michailidi, E.; Tzortzakis, N. Physiological and biochemical responses of Lavandula angustifolia to salinity under mineral foliar application. Front. Plant Sci. 2018, 9, 1-23. [CrossRef]

36. Sandberg, A.-S. Bioavailability of minerals in legumes. Br. J. Nutr. 2002, 88, 281-285. [CrossRef]

37. Schlemmer, U.; Frølich, W.; Prieto, R.M.; Grases, F. Phytate in foods and significance for humans: Food sources, intake, processing, bioavailability, protective role and analysis. Mol. Nutr. Food Res. 2009, 53, 330-375. [CrossRef]

38. Zou, T.; Xu, N.; Hu, G.; Pang, J.; Xu, H. Biofortification of soybean sprouts with zinc and bioaccessibility of zinc in the sprouts. J. Sci. Food Agric. 2014, 94, 3053-3060. [CrossRef]

39. Lingyun, Y.; Jian, W.; Chenggang, W.; Shan, L.; Shidong, Z. Effect of Zinc Enrichment on Growth and Nutritional Quality in Pea Sprouts. J. Food Nutr. Res. 2016, 4, 100-107.

40. Park, S.A.; Grusak, M.A.; Oh, M.M. Concentrations of minerals and phenolic compounds in three edible sprout species treated with iron-chelates during imbibition. Hortic. Environ. Biotechnol. 2014, 55, 471-478. [CrossRef] 
41. Przybysz, A.; Wrochna, M.; Małecka-Przybysz, M.; Gawrońska, H.; Gawroński, S.W. Vegetable sprouts enriched with iron: Effects on yield, ROS generation and antioxidative system. Sci. Hortic. 2016, 203, $110-117$. [CrossRef]

42. Afify, A.E.M.M.R.; El-Beltagi, H.S.; El-Salam, S.M.A.; Omran, A.A. Bioavailability of iron, zinc, phytate and phytase activity during soaking and germination of white sorghum varieties. PLoS ONE 2011, 6, 1-7. [CrossRef] [PubMed]

43. Liang, J.; Han, B.Z.; Nout, M.J.R.; Hamer, R.J. Effect of soaking and phytase treatment on phytic acid, calcium, iron and zinc in rice fractions. Food Chem. 2009, 115, 789-794. [CrossRef]

44. Frei, M.; Tetteh, R.N.; Razafindrazaka, A.L.; Fuh, M.A.; Wu, L.B.; Becker, M. Responses of rice to chronic and acute iron toxicity: Genotypic differences and biofortification aspects. Plant Soil 2016, 408, 149-161. [CrossRef]

45. Tomasi, N.; Pinton, R.; Dalla Costa, L.; Cortella, G.; Terzano, R.; Mimmo, T.; Scampicchio, M.; Cesco, S. New "solutions" for floating cultivation system of ready-to-eat salad: A review. Trends Food Sci. Technol. 2014, 46, 267-276. [CrossRef]

46. Di Gioia, F.; Avato, P.; Serio, F.; Argentieri, M.P. Glucosinolate profile of Eruca sativa, Diplotaxis tenuifolia and Diplotaxis erucoides grown in soil and soilless systems. J. Food Compos. Anal. 2018, 69, 197-204. [CrossRef]

47. Petropoulos, S.A.; Fernandes, Â.; Calhelha, R.C.; Di Gioia, F.; Kolovou, P.; Barros, L.; Ferreira, I.C.F.R. Chemical composition and bioactive properties of Cichorium spinosum L. in relation to nitrate/ammonium nitrogen ratio. J. Sci. Food Agric. 2019. [CrossRef]

48. Rouphael, Y.; Kyriacou, M.C. Enhancing quality of fresh vegetables through salinity eustress and biofortification applications facilitated by soilless cultivation. Front. Plant Sci. 2018, 9, 1-6. [CrossRef]

49. Raviv, M.; Lieth, J.H. Significance of Soilless Culture in Agriculture. In Soilless Culture Theory and Practice; Raviv, M., Lieth, J.H., Eds.; Elsevier: Amsterdam, The Nederlands, 2007; pp. 1-11.

50. Orsini, F.; Kahane, R.; Nono-Womdim, R.; Gianquinto, G. Urban agriculture in the developing world: A review. Agron. Sustain. Dev. 2013, 33, 695-720. [CrossRef]

51. Bonasia, A.; Lazzizera, C.; Elia, A.; Conversa, G. Nutritional, biophysical and physiological characteristics of wild rocket genotypes as affected by soilless cultivation system, salinity level of nutrient solution and growing period. Front. Plant Sci. 2017, 8, 15. [CrossRef]

52. Xiao, Z.; Lester, G.E.; Luo, Y.; Wang, Q. Assessment of vitamin and carotenoid concentrations of emerging food products: Edible microgreens. J. Agric. Food Chem. 2012, 60, 7644-7651. [CrossRef] [PubMed]

53. Sun, J.; Xiao, Z.; Lin, L.-Z.; Lester, G.E.; Wang, Q.; Harnly, J.M.; Chen, P. Profiling polyphenols in five Brassica species microgreens by UHPLC-PDA-ESI/HRMS(n). J. Agric. Food Chem. 2013, 61, 10960-10970. [CrossRef] [PubMed]

54. Di Gioia, F.; Santamaria, P. Microgreens - Novel Fresh and Functional Food to Explore All the Value of Biodiversity; Eco-logica Srl: Bari, Italy, 2015; ISBN 9788890928932.

55. Ebert, A.W.; Wu, T.H.; Yang, R.Y. Amaranth sprouts and microgreens - A homestead vegetable production option to enhance food and nutrition security in the rural-urban continuum. In Proceedings of the Regional Symposium on Sustaining Small-Scale Vegetable Production and Marketing Systems for Food and Nutrition Security (SEAVEG2014), Bangkok, Thailand, 25-27 February 2014; pp. 233-244.

56. Xiao, Z.; Codling, E.E.; Luo, Y.; Nou, X.; Lester, G.E.; Wang, Q. Microgreens of Brassicaceae: Mineral composition and content of 30 varieties. J. Food Compos. Anal. 2016, 49, 87-93. [CrossRef]

57. Kyriacou, M.C.; Rouphael, Y.; Di Gioia, F.; Kyratzis, A.; Serio, F.; Renna, M.; De Pascale, S.; Santamaria, P. Micro-scale vegetable production and the rise of microgreens. Trends Food Sci. Technol. 2016, 57, 103-115. [CrossRef]

58. Di Gioia, F.; Renna, M.; Santamaria, P. Sprouts, Microgreens and "Baby Leaf" Vegetables. In Minimally Processed Refrigerated Fruits and Vegetables. Food Engineering Series; Yildiz, F., Wiley, R., Eds.; Springer: Boston, MA, USA, 2017; pp. 403-432.

59. Di Gioia, F.; De Bellis, P.; Mininni, C.; Santamaria, P.; Serio, F. Physicochemical, agronomical and microbiological evaluation of alternative growing media for the production of rapini (Brassica rapa L.) microgreens. J. Sci. Food Agric. 2017, 97, 1212-1219. [CrossRef] [PubMed]

60. Kyriacou, M.C.; El-nakhel, C.; Graziani, G.; Pannico, A.; Soteriou, G.A.; Giordano, M.; Ritieni, A.; Pascale, S. De Functional quality in novel food sources: Genotypic variation in the nutritive and phytochemical composition of thirteen microgreens species. Food Chem. 2019, 277, 107-118. [CrossRef] 
61. Renna, M.; Di Gioia, F.; Leoni, B.; Mininni, C.; Santamaria, P. Culinary Assessment of Self-Produced Microgreens as Basic Ingredients in Sweet and Savory Dishes. J. Culin. Sci. Technol. 2017, 15, 126-142. [CrossRef]

62. Petropoulos, S.; Di Gioia, F.; Ntatsi, G. Vegetable Organosulfur Compounds and their Health Promoting Effects. Curr. Pharm. Des. 2017, 23, 2850-2875. [CrossRef]

63. Anderson, D.L.; Henderson, L.J. Comparing Sealed Chamber Digestion with Other Digestion Methods Used for Plant Tissue Analysis. Agron. J. 1988, 80, 549. [CrossRef]

64. Ozores-Hampton, M.; Di Gioia, F.; Sato, S.; Simonne, E.; Morgan, K. Effects of nitrogen rates on nitrogen, phosphorous, and potassium partitioning, accumulation, and use efficiency in seepage-irrigated fresh market tomatoes. HortScience 2015, 50, 1636-1643. [CrossRef]

65. Hanlon, E.A.; Gonzalez, J.S.; Bartos, J.M. Mehlich 1 Extractable P, Ca, $\mathrm{Mg}, \mathrm{Mn}, \mathrm{Cu}$ and $\mathrm{Zn}$; University of Florida: Gainesville, FL, USA, 1997.

66. Plank, C.O. Plant analysis reference procedures for the southern region of the United States. South Coop. Ser. Bull. 1992, 368, 68.

67. Munter, R.C.; Halverson, T.L.; Anderson, R.D. Quality assurance for plant tissue analysis by ICP-AES. Commun. Soil Sci. Plant Anal. 1984, 15, 1285-1322. [CrossRef]

68. Ramezani, M.; Seghatoleslami, M.; Mousavi, G.; Sayyari-Zahan, M.H. Effect of salinity and foliar application of iron and zinc on yield and water use efficiency of Ajowan (Carum copticum). Int. J. Agric. Crop Sci. 2012, 4, 421-426.

69. Moghimipour, Z.; Sourestani, M.M.; Ansari, N.A.; Ramezani, Z. The effect of foliar application of zinc on essential oil content and composition of holy basil [Ocimum sanctum] at first and second harvests. J. Essent. Oil-Bear. Plants 2017, 20, 449-458. [CrossRef]

70. Hassanpouraghdam, M.; Gohari, G.; Tabatabaei, S.; Dadpour, M.; Shirdel, M. NaCl salinity and Zn foliar application influence essential oil composition of basil (Ocimum basilicum L.). Acta Agric. Slov. 2011, 97, 4-9. [CrossRef]

71. Ghorbanpour, M.; Asgari Lajayer, H.; Hadian, J. Influence of copper and zinc on growth, metal accumulation and chemical composition of essential oils in sweet basil (Ocimum basilicum L.). J. Med. Plants 2016, 15, 132-144.

72. Ahl, H.A.H.S.; Omer, E.A. Effect of spraying with zinc and / or iron on growth and chemical composition of coriander (Coriandrum sativum L.) harvested at three stages of development. J. Med. Food Plants 2009, 1, $30-46$.

73. Hanif, M.A.; Nawaz, H.; Ayub, M.A.; Tabassum, N.; Kanwal, N.; Rashid, N.; Saleem, M.; Ahmad, M. Evaluation of the effects of Zinc on the chemical composition and biological activity of basil essential oil by using Raman spectroscopy. Ind. Crops Prod. 2017, 96, 91-101. [CrossRef]

74. Rietra, R.P.J.J.; Heinen, M.; Dimkpa, C.O.; Bindraban, P.S. Effects of nutrient antagonism and synergism on yield and fertilizer use efficiency. Commun. Soil Sci. Plant Anal. 2017, 48, 1895-1920. [CrossRef]

75. Gupta, N.; Ram, H.; Kumar, B. Mechanism of Zinc absorption in plants: Uptake, transport, translocation and accumulation. Rev. Environ. Sci. Biotechnol. 2016, 15, 89-109. [CrossRef]

76. Ricachenevsky, F.K.; de Araújo Junior, A.T.; Fett, J.P.; Sperotto, R.A. You shall not pass: Root vacuoles as a symplastic checkpoint for metal translocation to shoots and possible application to grain nutritional quality. Front. Plant Sci. 2018, 9, 1-6. [CrossRef] [PubMed]

77. Institute of Medicine Dietary Reference Intakes for Vitamin A, Vitamin K, Arsenic, Boron, Chromium, Copper, Iodine, Iron, Manganese, Molybdenum, Nickel, Silicon, Vanadium, and Zinc; The National Academies Press: Washington, DC, USA, 2001; ISBN 0309072794.

78. De Dorlodot, S.; Lutts, S.; Bertin, P. Effects of ferrous iron toxicity on the growth and mineral composition of an interspecific rice. J. Plant Nutr. 2005, 28, 1-20. [CrossRef]

79. Giordano, M.; El-Nakhel, C.; Pannico, A.; Kyriacou, M.C.; Stazi, S.R.; De Pascale, S.; Rouphael, Y. Iron biofortification of red and green pigmented lettuce in closed soilless cultivation impacts crop performance and modulates mineral and bioactive composition. Agronomy 2019, 9, 290. [CrossRef]

80. Cecílio Filho, A.B.; Mendoza Cortez, J.W.; de Sordi, D.; Urrestarazu, M. Common Chicory Performance as Influenced by Iron Concentration in the Nutrient Solution. J. Plant Nutr. 2015, 38, 1489-1494. [CrossRef]

81. Assimakopoulou, A. Effect of iron supply and nitrogen form on growth, nutritional status and ferric reducing activity of spinach in nutrient solution culture. Sci. Hortic. 2006, 110, 21-29. [CrossRef] 
82. Hernández-Castro, E.; Trejo-Téllez, L.I.; Gómez-Merino, F.C.; Rodríguez-Mendoza, M.N.; Sánchez-García, P.; Robledo-Paz, A. Bioaccumulation of iron, selenium, nitrate, and proteins in chard shoots. J. Soil Sci. Plant Nutr. 2015, 15, 694-710. [CrossRef]

83. Di Gioia, F.; Gonnella, M.; Santamaria, P. Contribution of Leafy Vegetables to Dietary Nitrate Intake and Regulations. In Nitrate in Leafy Vegetables: Toxicity and Safety Measures; Umar, S., Naser, A., Nafees, A., Eds.; I.K. International Publishing House: New Delhi, India, 2013; pp. 1-16.

84. Greer, F.R.; Shannon, M. Infant methemoglobinemia: The role of dietary nitrate in food and water. Pediatrics 2005, 116, 784-786. [CrossRef]

85. Di Gioia, F.; Gonnella, M.; Buono, V.; Ayala, O.; Santamaria, P. Agronomic, physiological and quality response of romaine and red oak-leaf lettuce to nitrogen input. Ital. J. Agron. 2017, 12, 47-58. [CrossRef]

86. Di Gioia, F.; Gonnella, M.; Buono, V.; Ayala, O.; Cacchiarelli, J.; Santamaria, P. Calcium cyanamide effects on nitrogen use efficiency, yield, nitrates, and dry matter content of lettuce. Agron. J. 2017, 109, 354-362. [CrossRef]

87. Colonna, E.; Rouphael, Y.; Barbieri, G.; De Pascale, S. Nutritional quality of ten leafy vegetables harvested at two light intensities. Food Chem. 2016, 199, 702-710. [CrossRef]

(C) 2019 by the authors. Licensee MDPI, Basel, Switzerland. This article is an open access article distributed under the terms and conditions of the Creative Commons Attribution (CC BY) license (http://creativecommons.org/licenses/by/4.0/). 